\title{
The Benefits of Continuing Teaching English Remotely at the German Jordanian University after Covid-19 Pandemic
}

\author{
Iman Shashaa, Bassmah B. Al Taher \\ School of Basic Sciences and Humanities, German Jordanian University, Amman, Jordan
}

Received September 14, 2020; Revised October 26, 2020; Accepted November 29, 2020

\section{Cite This Paper in the following Citation Styles}

(a): [1] Iman Shashaa, Bassmah B. Al Taher, "The Benefits of Continuing Teaching English Remotely at the German Jordanian University after Covid-19 Pandemic," Universal Journal of Educational Research, Vol. 8, No. 12, pp. 6844 6852, 2020. DOI: 10.13189/ujer.2020.081250.

(b): Iman Shashaa, Bassmah B. Al Taher (2020). The Benefits of Continuing Teaching English Remotely at the German Jordanian University after Covid-19 Pandemic. Universal Journal of Educational Research, 8(12), 6844 - 6852. DOI: 10.13189/ujer.2020.081250.

Copyright $\bigcirc 2020$ by authors, all rights reserved. Authors agree that this article remains permanently open access under the terms of the Creative Commons Attribution License 4.0 International License

\begin{abstract}
The implementation of teaching English online parallel to its on-campus courses has become a necessity more than a supplement. After the spread of the Corona virus, Covid-19, online teaching has become the only alternative to maintain a proper education in Jordan, especially at the German Jordanian University (GJU). The pandemic, despite its negativity, has opened doors to innovative ways in education and encouraged everyone to continue with online education. With the positive impact of online teaching for higher education, this paper concentrates on the need to continue online teaching as parallel to classroom teaching after the end of the pandemic since its advantages have proven it to be effective and beneficial. The study uses a survey approach administered to GJU undergraduate students, who have taken English lectures online during the pandemic. The variables are reliable with Cronbach alpha $\alpha=0.736$, proving that students are interested and do need to take English courses online as a parallel form but not as a substitute. The results show that students are in favor of the parallel leaning for the multiple benefits it offers. E-learning is the new gateway for GJU to adopt the parallel stream in higher education, and can be used due to its advantage.
\end{abstract}

Keywords Benefits of Distance Learning, GJU E-Learning, Parallel Method, Ongoing Online Teaching, Higher Education, Second Language Learning, TEFL

\section{Introduction}

When sirens echoed throughout the governorates of Jordan, people finally realized how serious the pandemic was, and taking extreme measure in education became inevitable. Schools and universities were shut down and transferred to online teaching in mere 48 hours without any further warning. Educators from all districts of the country used many social platforms to maintain the same feel of a classroom when teaching online. Apps such as Zoom, Google classroom, and Microsoft Teams have become the top grossing programs educators referred to when teaching higher education online. Students and teachers at first found it difficult, confusing, and somehow intimidating when using the new and the unknown set of features presented to them by their universities.

Many educators in higher education lacked proper training, and the pandemic made it no easier for them when it came to implement online teaching in such short notice. However, as the months passed, online teaching has become secondhand nature to many educators, and students have begun to feel comfortable and see its advantages. During the summer course of 2020, students and teachers discovered how convenient and accessible online education had become, as many students were able to take up part-time summer jobs and attend classes during their breaks without the hassle of leaving the workplace and wasting time on transportation. Online education, despite the unfortunate circumstance it has sprung from, is not new in Jordan, especially at the German Jordanian 
University.

Online education has been developing since informatization and globalization spread rapidly in the twentieth century. Many colleges now offer courses and degrees where online classes are given via computers and TV channels. This concept has become popular and is encouraged globally serving learners who work during the day and cannot attend lectures physically. The University of Phoenix in 1989 was the first university to "launch a fully online collegiate institution that offered both bachelor and master's degrees" [26]. Many universities followed in pursuit, and "today it is estimated that 1 out of 4 college students are enrolled in at least one online class. In 2009 there were over 4.5 million students taking online classes" [27]. With technology improving drastically, online programs have earned its proper respect, as education experts predict that distance education will continue to expand and become more accessible. Nowadays, distant learning has become more sophisticated and approved by most reputable universities around the world. Apparently $33 \%$ of college students are registered for an online course; schools and employers "are recognizing that online courses can be just as effective - and sometimes more effective than classroom courses. As universities embrace online learning, so does the acceptance of online degrees" [26].

Jordanians have always seen education as one of their major concerns. Students aim for higher education with great enthusiasm, as 276903 students are registered in undergraduate programs at various public and private universities [23]. With regular classes prevailing on campus, Jordanian universities have begun taking "small measures towards achieving distance learning" [1]. His Majesty King Abdullah II in the Seventh Discussion Paper in 2017 "expressed his ambition for Jordan to be the leader in the process of modernizing education in the Arab world" [12]. He expressed his desire to have Jordan as a "pioneer of the transformation into a knowledge society, through a modern education system that enables Jordanian students to acquire the skills of how to learn in the age of computers and the Internet in order to survive the world knowledge and creativity" [12]. In line with this royal ambition and in response to a letter from His Majesty King Abdullah II to the Prime Minister, in March 2015, a National Committee for Human Resources Development was established to create the National Strategy for Human Resources Development (2016-2025). This strategy emphasizes the need to develop the infrastructure for modern technological devices used in higher educational institutions, and to promote the use of open source educational resources to improve teaching, learning and scientific research [11]. Jordanian universities have begun to pay more attention to E-learning in order to keep pace with the global trend related to the integration of modern technology. The Jordanian Ministry of Education Strategic Plan (2011-2018) "assures the achievement of educational outputs, while keeping pace with the rapid development of information and commutation technology, the provision of sustainable smart e-learning resources" [32].

The Higher Education Council approved the E-Learning Policies paper "The Future of Higher Education in Jordan: Reality, Ambition and Challenges" [12]. The paper deals with higher education and digital transformation that would go through three phases between the years 2020-2022 and integrate an E-learning approach with a functional and sustainable method. Distance learning is used as a supplement and not as a replacement to on-campus communication. It is "rather an important component for higher education and a tool to improve universities' competitiveness in regards to cultivating an "innovative educational environment" [1].

Since the onset of the lockdown and the closure of all University campuses in March 2020 due to the COVID-19 crisis, and in light of the challenges of the education sector, the Council of Higher Education took a number of measures to organize distance learning. Experienced committees of academic experts were established to evaluate E-learning and testing. The only available alternative to a regular face-to-face education is online learning, and it is the only way for students to proceed with their studies. Adapting to the new circumstances during the pandemic and making the best out of it is a blessing in disguise for many Jordanians. The spread of Covid-19 did close most educational institutions temporarily, but this global health crisis prompted E-learning as a challenge to maintain the educational process and maintain the process of learning.

Despite the lockdown, the summer semester of 2020 had to continue, and so the Minister of Higher education took the decision to resume studying in all public and private universities online. The German Jordanian University is among those who have worked hard to make this experience successful by implementing E-learning even before the pandemic. E-learning has always been available in the Jordanian educational background, but not fully acceptable as a complete methodology of teaching at Jordan universities. Attendance has always been mandatory and being present in class meant not missing $85 \%$ of on-campus lectures, and if a student fails to attend all lectures, he is deprived. This has caused a problem for many working students who are unable to take English courses.

All GJU senior students have a mandatory year to spend in Germany, which is known as their German year. It is part of their undergraduate program where they take certain courses at German universities and an internship to gain experience [2]. Those students who are in Germany are unable to take English courses on campus; students also face the same problem when traveling to do official paperwork, like residency papers in their home countries or the countries they and their families reside in. Therefore, having E-learning as part of the higher educational program, whether it be a substitute or a supplement to the 
traditional system has become necessary to ease the pressures on senior or graduate students at GJU.

Using the John M. Keller's motivational model, distant learning can be seen from a different perspective, as being a required form in future education. Students at GJU are requested to voice their opinions about distant learning, and their needs cannot be ignored when wanting an education. If E-learning becomes a system continued as a parallel form of education for GJU students, many undergraduate students will have the opportunity to take courses online while traveling abroad or when they are taking lectures on another campus. They can also take online English courses to maintain their language while in Germany. In order to discover whether online education can be successful in parallel form, it is important to understand if motivation can be achieved. This paper focuses on how undergraduate students are motivated currently when taking their classes online due to the pandemic and predict the success of keeping distant learning for students in the future at GJU when taking English courses in a parallel method, on campus and online.

The concept of keeping online education even after the pandemic is an opportunity to embrace, allowing students to use online education as a method for obtaining an education whilst having the freedom to attend the other half of their lectures on campus. Moreover, this paper aims at making this concept of parallel education a transcending process that can be agreeable and accessible for higher educational institutions, especially at the German Jordanian University.

\section{Literature Review}

With the world becoming more interconnected globally, the need to learn English has become an important requirement for higher education. When teaching a second language, many educators assume that anxiety is inevitable, and it has always been thought to cause anxiety for both student and teacher. Research shows that according to the skill learned by students, whether it be writing, listening, speaking, or reading, the results show that when teaching a foreign language, anxiety is almost absent in the classroom [4], [5]. Hence, when teaching a foreign language, students' interactivity is what a teacher focuses on. Interactivity is mostly found in regular classes with face-to-face interactions.

Under the new circumstances of the pandemic, teachers have come to realize that a successful interaction can be achieved with online classes as well. Distance learning is no new concept, as it has rapidly developed into a new form of teaching and learning where materials have become digitalized and teachers equipped with very useful iTools, question banks and an endless database. Most university students in Jordan are in their early twenties, and studies show that students under the age of thirty read differently due to the widespread of smart phones. Today digital devices are the number one source for accessing texts, and students are now "switching, zapping [and] zooming" [6] through their devices.

This is an advantage for teachers to link education to multimedia texts to present a dynamic interactive program, "creating innovative literary and aesthetic experiences" [22]. The advancement of the internet has set the grounds for more rapid development of E-learning. Many studies show that hybrid or combined learning "provides the most efficient and effective instruction experience by combining delivery modalities" [22]. However, the lack of access to technology in education "continues to be a challenge with novel education technologies" [7]. Nowadays, the advancement of the internet has allowed more underprivileged students to continue with their education. A main promise of online technologies is that they can "increase access to nontraditional and underserved students by bringing a host of education resources and experiences to those who may have limited access to on-campus...higher education" [3].

The "availability of distance education has provided education opportunities to millions [30]. Blended courses, which are mainly a "combination of online and in-class instruction with reduced in-class seat time for students" [30], can enhance the employability of higher education students. It is "widely adopted across higher education" [9] with some scholars referring to it as the "New traditional Model" [31]. Various approaches in adult education mainly focus on how to create a communicative language teaching (CLT), where "motivation, discipline, class size and the diversity" [23]. are important in teaching a second language, but how can interactivity and motivation remain when the classroom is transferred online?

Distance learning is no new concept, as many universities pioneered in online education by recording lectures and using teacher, student online interaction that allows flexible education [10]. "E-learning is proving to be a great tool in leveraging the barriers of equity and access" [10]. For a limitless classroom, students from all walks of life have an opportunity to get an education with no barriers. The best motivation for distance learning is to make it "more exploratory by using multi-tasking" [10]. Students would be able to take their quizzes, do class activities, and more with their peers online, making the online experience another form. "Asynchronous teaching enables the student to send emails to the teacher anytime. The text chat and voice chat are matrixes for synchronous learning" [10].

However, can distance learning replace the traditional form of education surrounded by four walls? Students have a right to see and meet their teachers, classmates, and get a chance to experience life on campus. When the pandemic of Covid-19 hit, and higher education transferred online, students and teachers were forced to use E-learning but in a 
traditional form of teaching. With the reopening of universities in Jordan for the fall semester, the on-campus experience is mandatory for specialty courses, but wouldn't it be more beneficial if students followed a 50\% on campus experience and took the rest of their classes online? Education should not lose any of its main characteristics; whether face-to-face or online. Studies show that "quality education presents a challenge, evidenced by many definitions of what constitutes its fundamental components" [7]. Studies continue to tackle issues in teaching to reach the best possible means to have a better impact on student's education.

The continuation of online teaching in parallel to the regular undergraduate program is an option this paper is trying to explore. This study addresses several implications, possible future directions, and the possibility to continue teaching English courses for higher education students as a blended form of learning. These findings can be used across higher education in this new world where the advancement of technology in the communication and information field is increasing rapidly and is allowing more changes and methods to improve the access and the success of students to learn online. It concludes that the best way to continue online education in Jordan's higher educational programs is to use both methods of teaching that allow flexibility and ease for both students and teachers. The advantages the parallel stream offers are seen in the following data taken from the perspective of students and are confirmed by comprehensive analysis.

\section{Research Theory}

Motivation is the key to success in every field, especially in the learning process. It has a positive influence on the student's academic achievement, and it is vital in higher education. To be able to motivate students, it is essential that teachers verity the students' needs when attending classes and lectures especially now with the new online classes due to the spread of COVID-19. Students are already under pressure due to the new E-learning system that differs dramatically from face-to face lectures that has close contact to peers and within a classroom environment that encourages and motivates them. Students need to work and travel while studying. Having a system that takes into consideration their needs and respects each student's preference motivates them and directs them towards a positive learning.

What better way to ensure a positive learning than John M. Keller's ARCS motivational modal, which stands for Attention, Relevance, Confidence, and Satisfaction. It "is an approach to solving learning-related problems that are inherent in the poor motivation of learners. This model is especially useful for designers of e-learning programs so that they can develop exciting activities that will boost the educational process" [28]. When the elements of attention, relevance, confidence, and satisfaction are applied by instructors, motivation is encouraged in students [22]. "Originally designed to study how to effectively motivate learning, Keller's ARCS Model [shows]...that people will engage in an activity if they believe that they will succeed at it and...their personal needs [satisfied]" [21].

Keller states that having control of motivation in a classroom is quite impossible, yet the instructor can simulate motivation and when they create learning environments based on stimulation, students are bound to interact and feel inspired to participate [21]. However, online teaching is challenged in maintaining students' attention. The teacher needs to stimulate their perception and arouse their interest by showing them a different point of view that is different from their usual on-campus lectures. One way is to include arousing their curiosity in different ways to conduct research and enhance their critical thinking. To avoid boredom, instructors should "use multiple methods and approaches such as videos, discussion groups, lectures as well as opportunities for collaborative learning in order to maintain interest in different types of learners" [28].

The element that teachers use most in teaching especially at the German Jordanian University is reminding students of the importance of English language in their future. The market all around the world specifies the need of high language proficiency. In ARCS, this is referred to as "Goal orientation" where the teachers "have to explain to their students why the new knowledge has the potential to help them immediately... [and] in the future" [21].

This paper concentrates on the choices and needs of the students, which are important elements explained in Keller's ARCS: “Allowing students the opportunity to choose for themselves the method they consider best in relation to achieving their learning goal" [28]. It emphasizes their "preferences for specific learning methods or tools that they perceive most effective" [28]. Motivation is key to what is called motivational science, and the fact that students' consideration is key to a successful educational environment, research efforts focus on the needs of students and create a system around those needs [29]. The personal involvement of the students should be fostered as it is "useful to provide learners with some degree of control over the learning process" [28], which creates a sense of independence within them. Explained further, it "makes them believe that they are responsible for their own learning" [28].

With the ARCS model in mind, preferences of the students are taken from the results of the survey in order to observe whether online learning is desired. "A successful learning program needs students who feel satisfied and proud of what they are doing within it" [28]. This satisfaction comes through intrinsic and extrinsic motivation, and when they are provided with feedback and reinforcement, these learners will "appreciate the results" and will find the motivation to learn [28]. 
Grades and assessment are a major part of satisfying students. By applying ARCS and its adaptation on E-learning, Keller provides examples of motivational "strategies and a case description of the motivational enhancement of an instructional module in three different delivery contexts: classroom instruction, blended learning, and eLearning" [21]. It includes the "results of the analysis and resulting revisions to both blended learning version of the module and an adaptation to an e-learning version of it" [21]. His examples of learning environments and pedagogical strategies include different varieties such as distance learning, "flipped classroom, mobile (M-) learning," blended learning, massive open online courses (MOOCs), hybrid learning, virtual worlds and even "traditional classroom learning" [27]. Keller believes that despite the excitement of having technology on the side of E-learning, many educators are not as excited as they should be. He also says that this applies to students who are "sometimes excited by new techniques and technologies, but their interest is frequently short-lived. Just as students are not always motivated to learn, teachers are not always motivated to teach" [27].

Taking into consideration this gradual decrease in "excitement" from both student and teacher, E-learning during the pandemic has proven that distance learning on the long run can and will prosper if the right measures are taken properly. The data and discussion to follow show how motivated learners are, and a parallel method is something to be considered.

\section{Methodology}

\section{Research Design}

A survey-based approach was used for this research, as a questionnaire was distributed to undergraduate students at GJU. The questions composed asked whether undergraduate students found it necessary to continue online courses even after the pandemic of Covid-19 ends. The questions were categorized into three sections, most of them consisted dichotomous questions that were sent to students via their institutions' email. The dichotomous questions (yes/no) were used to reach a clear distinction of students' experience of online learning and their opinions; moreover, this approach saved time students were desperately in need, as they were constantly under pressure to complete various online activities, quizzes, and exams for their other online courses.

The first and second parts consisted of questions meant to collect demographic data in order to see the students' experience with online courses and how much time they had spent attending. The questions were related to the availability of this option and the involvement of the students who were learning English online and whether they wished to have their English courses parallel to their regular classes on campus after coming back to university.
The questions were tailored to check their ability in taking classes online and distinguishing their preferences. The students could have the option of choosing between taking an English course online or taking it at the University as face-to-face regular classes.

Moreover, the questions were related to the preferred details of teaching and assessment in addition to the suggestions for improvement. This included attendance, family supervision and exams. The most important part of the survey was asking students about the advantages of online learning, making this a direct connection between the distant learning and parallel studies.

The advantages students have found in E-learning are immense, as it explores options such as travel, work, or the ability to cope in any situation that relates to their attendance in regular classes online.

\section{Population and Sample}

The targeted students took English Courses online during the Second Semester of 2019/2020 and were taking them during the Summer Semester of 2019/2020. The survey was distributed in July to 217 participants who were well-informed of the purpose of the survey during the Summer Semester of 2019/2020. A total of $(N=116)$ students responded to the survey.

The sample of participant students of $(N=116)$ undergraduate students from different majors and were taking English level six online at the School of Basic Sciences and Humanities, GJU, during the Second and Summer Semesters of the Academic Year of 2019/2020 due to the lockdown caused by the global spread of COVID-19.

According to the demographic data collected, the participants ranged between the ages of 18 to $25(41 \%$ ranged between 18 and 20 and 59\% between 21 and 25). The majority of the participants were male $60 \%$ and $40 \%$ were female. In addition, most of the participants were third year students $34.8 \%, 23.5 \%$ were fourth year students; $20.9 \%$ were second year students; $10.4 \%$ were first year; $8.7 \%$ were fifth year, and less than $2 \%$ were between fifth and sixth year and more.

The collected data from the survey has shown that $65 \%$ of the participants had taken seven or more courses online, whilst $10 \%$ had

taken five courses, $9.6 \%$ took six courses, $7.8 \%$ took three courses, and only $3.5 \%$ took two courses; $1.7 \%$ took four courses, and $1.7 \%$ took only one course. A majority of the participants spent more than 6 hours online per week $(52 \%), 22 \%$ spent $5-6$ hours, $17 \%$ spent $3-4$ hours and only $9 \%$ spent $1-2$ hours.

\section{Data Collection and Analysis}

To ensure the validity of the study, the relationship between the dependent variables DV = advantages of online courses, with the independent variable IV $=$ Parallel 
online education, was taken into account. A one-way ANOVA test in the Statistical Package for Social Sciences (SPSS) was used to analyze the inferential statistics to see the constructive relationship between the variables [21], because it is easier to see the difference of values and means between the DV and the IV [21]. When performing the test, the mean values of the dependent values are taken into contrast with the differences of means and are analyzed accordingly as to how these values affect the controlled independent variable [21].

The null hypothesis of this study is that there is no relationship between the DV and IV, and the alternative hypothesis is that there is a significant relationship between the means of the variables, making parallel online education the targeted desire for students of higher education at GJU.

\section{Results and Discussion:}

First, the testing is conducted in order to observe the reliability of the study and reject the null hypothesis. An ordinal scale is the frame of the students' responses, as the items of the independent variable are measured as (yes $=1$ and no $=2$ ). The reliability of the study is calculated according to Cronbach's alpha $\alpha$, and the result was 0.736 . This score is acceptable and is within range, for when an $\alpha$ $=1.00$, it shows a perfect internal consistent reliability, and when an $\alpha=0.00$, it indicates no consistency in measurement [25].

The DV's mean of 15 items (as seen in table 1) are calculated and merged into one variable in order to conduct a one-way ANOVA test and compare means between the DV and IV:

Table 1. Advantages of Online Courses

\begin{tabular}{|c|c|c|}
\hline Questions & Yes & No \\
\hline IV: I think online classes is a good parallel to continue & $57 \%$ & $43 \%$ \\
\hline \multicolumn{3}{|l|}{ DV items: } \\
\hline I gain a lot of information with Distant Learning & $53 \%$ & $47 \%$ \\
\hline Face to face communication needs a lot of effort & $42 \%$ & $58 \%$ \\
\hline I am more comfortable with online communication & $54 \%$ & $46 \%$ \\
\hline I prefer to record the whole lecture & $95 \%$ & $5 \%$ \\
\hline I need to go back to the recording & $84 \%$ & $16 \%$ \\
\hline I save a lot of time and money by not going to university & $83 \%$ & $17 \%$ \\
\hline I am able to take a part time job due to online courses & $62 \%$ & $38 \%$ \\
\hline I think a complete course can be taken online without any difficulty & $61 \%$ & $39 \%$ \\
\hline I prefer to communicate from behind a screen & $39 \%$ & $61 \%$ \\
\hline I prefer to communicate with my peers & $71 \%$ & $29 \%$ \\
\hline I prefer to communicate only with my teacher & $36 \%$ & $64 \%$ \\
\hline I prefer to have all classes online even after pandemic & $39 \%$ & $61 \%$ \\
\hline I think students abroad will find distance education very useful & $87 \%$ & $13 \%$ \\
\hline Learning at home is as efficient as learning at university & $30 \%$ & $70 \%$ \\
\hline I can ask questions and get fulfilling answers from teachers online & $75 \%$ & $25 \%$ \\
\hline Online courses save time and money & $86 \%$ & $14 \%$ \\
\hline
\end{tabular}


The number of population $(N=116)$ remained as it is. According the homogeneity of variance, Levene statistics indicate a 5.734 with a significance of 0.18 . The normality of data distribution should be more than 0.05 , and the results show the normality of the test. Please see tables 2 and 3 for further details:

Table 2: Test of Homogeneity of Variances

\begin{tabular}{|c|c|c|c|c|c|}
\hline \multicolumn{2}{|c|}{} & $\begin{array}{c}\text { Levene } \\
\text { Statistic }\end{array}$ & df1 & df2 & Sig. \\
\hline \multirow{4}{*}{$\begin{array}{c}\text { DV } \\
\text { Mean }\end{array}$} & Based on Mean & 5.734 & 1 & 114 & .018 \\
\cline { 2 - 6 } & Based on Median & 5.371 & 1 & 114 & .022 \\
\cline { 2 - 6 } & $\begin{array}{c}\text { Based on Median } \\
\text { and with adjusted df }\end{array}$ & 5.371 & 1 & 106.270 & .022 \\
\cline { 2 - 6 } & $\begin{array}{c}\text { Based on trimmed } \\
\text { mean }\end{array}$ & 5.334 & 1 & 114 & .023 \\
\hline
\end{tabular}

Table 3: ANOVA

\begin{tabular}{|c|c|c|c|c|c|}
\hline DV Mean & $\begin{array}{c}\text { Sum of } \\
\text { Squares }\end{array}$ & df & $\begin{array}{c}\text { Mean } \\
\text { Square }\end{array}$ & F & Sig. \\
\hline $\begin{array}{c}\text { Between } \\
\text { Groups }\end{array}$ & 1.885 & 1 & 1.885 & 100.436 & .000 \\
\hline Within Groups & 2.139 & 114 & .019 & & \\
\hline Total & 4.024 & 115 & & & \\
\hline
\end{tabular}

The significance of the ANOVA is less than 0.01, an obvious case where the null hypothesis is rejected, and the true means of the varieties of the alternative are satisfied. This significance test interprets the difference between the means, showing that the results are real. A post-hoc test unnecessary because there are only two variables in this test.

The results indicate that being at home, away from distractions, avoiding traffic jams, doing work, internship, spending the year in Germany is a great motivation for the student to continue to have online classes. As per ARCS theory, the motivation of students is the key to success in learning. It indicates that their "preferences for specific learning methods or tools" [28] is the most effective.

Although students feel the need to communicate with their peers, they find more advantages in having the choice to do online courses. The results are in accordance with our predictions. They see major advantages of being able to take English courses online. Students also do not prefer mandatory attendance nor the supervision of parents. They prefer to take online exams without cameras. Their assessment (oral and written) should be done as a group, for most answers are not in compliance with one-to-one assessment.

The collected data from the survey has shown the following results: Most students have internet connection and Wi-Fi at all times. The internet does not hinder their studies and more than $77 \%$ have the accessibility to have online classes. $53 \%$ believes that students can be motivated to have online classes while almost $93 \%$ believe they are responsible enough to work independently, and around
$77 \%$ feel disciplined to do their HW without delay. As the study addresses students of English during the time of their Summer Semester, they find their English language skills improved as they can complete the course's requirements online without any difficulty.

When setting standards for E-learning and the need for improvement, the preference of students was taken into consideration. This suitable system is important as it attracts more students to register when this option is available; 636 students registered for the Summer Semester of 2019/2020, a great number that has not been seen for quite a while in the School of Basic Sciences and Humanities.

Students who are currently taking classes remotely, or have taken online courses recently at the German Jordanian University have shifted from face-to-face to online teaching due to the outbreak, making this survey effective in getting the best possible results. When we put our theories to the test and check the answers of the students to establish a baseline of the changes needed to have a better online education, most results are in accordance with our predictions. Students say that they find online exams more useful for knowledge assessment than paper based assessments. This confirms our predictions related to the students' opinions about exams in accordance with ARCS theory, where their preference provides the best satisfaction and thus motivation to learn.

As per the ARCS theory, educators know that the student's opinions are valuable when creating a new E-learning model or by developing the current model in use. The data collected indicate that students' opinions are not in accordance with the presumed idea that parents' supervision enhances E-learning. While allocating marks is considered a good incentive, students want their privacy, and most of them want to keep their cameras off and microphones muted. They would like to see their teacher and prefer to record meetings in order to go back to them when needed and have them as reference in the future.

\section{Conclusions}

When looking at the results, the majority of students has shown a tendency to take online education and the assumption of experiencing anxiety of learning a second language $[4,5]$ is diminished when online teaching follows the ARCS model, and students are more motivated and engaged in their level of English. Despite the widespread of distant learning [30], the pandemic has allowed governments to change their educational systems and encouraged online education to an extent that every home now follows this method. If the possibility of having online education alongside on campus lectures once the pandemic ends, this new form of bended learning will motivate distant learning even further, as [10] stated earlier.

Learning English online is suitable for higher education 
and is highly encouraged by the Jordanian Minister of Higher Education to continue even after the end of the Corona virus pandemic. This paper shows that students do benefit from the online experience to the fullest during the pandemic and wish to proceed with this experience. Students' opinion and standpoint of distance learning in parallel to their on-campus is a choice many students wish to see happen in the near future. Their opinions prove that they have "some degree of control" [28] over taking their English language courses online. This enables them to travel, work, or be anywhere else. Most students have access to the internet in order to take English level classes, and are motivated to take other courses online without the hassle of transportation and waiting endless hours for their lecture time.

Online education parallel to their on-campus courses proves to be beneficial since online courses on GJU E-learning are based on good grounds to continue with this process. The variety of assessments does not only motivate students to take the course seriously, but also flexibly. The survey confirms GJU students' interest, will, and need to have English courses online as a parallel form but not as a substitute, where $50 \%$ of the course can be taught on-campus, and $50 \%$ online. This ensures effectiveness of the system, and the pandemic has shown how useful online education is. Students' answers confirm their preference for regular face-to-face classes, but also wish to experience distant learning. Many of them are prepared and quite familiar with the procedures of online learning. Having the choice to proceed with this parallel system is the inherent part of ARCS and the science of motivation. Online courses are a solution for GJU students who are travelling, have part time jobs, or cannot attend regular classes for any other reason.

Hence motivation can be achieved online and caters to students' needs. Students are engaged with the various assessments presented, and many believe that a good education can be achieved whether online or on-campus. Thus, the future of GJU's English courses in parallel mode will open doors to new opportunities, especially when GJU students are forced to take their final year abroad in Germany. The research stresses on E-learning, for it allows students more space and freedom.

\section{Research Limitations}

This paper is only one aspect of how students benefit from distant learning. Other researches could include the perspective of teachers in order to get the best blended system that motivates both the teacher as well as the student. Moreover, the study is performed at one public university, and tested only on students taking English level six course, restricting the findings from being able to be generalized properly. Therefore, future research in this area are encouraged, especially when comparing online to on-campus courses at different universities in Jordan.

\section{Future Studies}

This paper has put out a conceptual framework of continuing online courses teaching English at the German Jordanian University. It is mainly based on the survey that checked the students' preference. Another series of future research suggestions can come out with expanding that theory by taking the point of view of teachers and academics at the University. This will provide more fields for providing the continuity of online courses for other schools and departments that teach Arabic, German or other humanities at the University. Further studies should include the financial aspect of these online courses. The point of view of administrators should be considered to see if the tuition fees of these courses should be changed according to their costs. Future studies can check the results of students taking online courses and compare them to those taking face-to-face lectures. More Jordanian universities should be included in further studies for continuing the online courses after the pandemic for the benefit of a larger number of students.

\section{REFERENCES}

[1] Al Nawas B., "Higher Education Council Reviews Distance Learning Experience," Jordan Times, Jordan, http://www.jordantimes.com/news/local/higher-educationcouncil-reviews-distance-learning-experience (accessed 9 September 2020).

[2] AlTaher Bassmah B., "The Necessity of Teaching Intercultural Communication in Higher Education," Journal of Applied Research in Higher Education. vol. 12, no. 3, pp. 506-516, 2019. https://www.emerald.com/insight /content/doi/10.1108/JARHE-04-2019-0082/full/html\#: :t ext $=$ Unlike $\% 20$ the $\% 20$ act $\% 20$ of $\% 20$ memorizing,in $\% 20$ gr oups $\% 20$ is $\% 20$ highly $\% 20$ effective.

[3] Aud Susan, Fox Mary Ann, "Status and Trends in the Education of Racial and Ethnic Groups," National Center for Education Statistics: Institute of Education Sciences, https://nces.ed.gov/pubs2010/2010015.pdf (accessed 14 Sep. 20)

[4] Bailey K. M., "Competitiveness and anxiety in adult second language learning: Looking at and through the diary studies.,"in H. W. Seliger, M. H. Long (eds), Classroom Oriented Research in Second Language Acquisition, Rowley, MA: Newbury House, 1983, pp.67-102.

[5] Brown J.D., Robson G., Rosenkjar P.R., "Personality, motivation, anxiety, strategies and language profeciencey of Japanese students," Motivation and Second Language Acquisition, vol. 23, pp. 361-398, 2001.

[6] Dawidowski C., "Lesen Digital Natives anders? Über die Wirkung der aktuellen Medienrevolution, Juliet, vol.2, 
2013, pp.7-15.

[7] Dziuban Charles, Graham R. Charles, Moskal Patsy D., Norberg Anders, Scicilia Nicole, "Blended learning: the new normal and emerging technologies," International Journal of Educational Technology in Higher Education, vol.15, no. 3, 2018. doi.org/10.1186/s41239-017-0087-5.

[8] Gee J. P., What video games have to teach us about learning and literacy? New York: Palgrave Macmillan, 2003.

[9] Graham C. R. "Emerging practice and research in blended learning," in M. G. Moore (ed.), Handbook of distance education, 3rd ed., New York, NY: Routledge, 2013, pp. 333-350.

[10] Guha A.S., Maji Subhashish. "E-learning: the latest spectrum in open and distance learning," Social Responsibility Journal, vol. 4, no. 3, pp.297-305, 2008. DOI: $10.1108 / 17471110810892820$.

[11] "Education for Properity Strategy," National Committee for Human Resources Development, https://www.hrd.jo/nation alstrategy, (accessed 10 September 2020).

[12] ibn Al Hussein A., "Developing Human Resources And Education Imperative For Jordan's Progress," King Abdullah II Official Website, 2017, https://kingabdullah.jo/en/discussion-papers/developing-hu man-resources-and-education-imperative-jordan $\%$ E2\% 80 $\% 99$ s-progress, (accessed 9 September 2020).

[13] "Jordan and Distance Learning Review," Council for Higher Education Accreditation, 2020, https://www.chea.org/jorda $\mathrm{n}$-and-distance-learning-review (accessed 11 September 2020).

[14] "Kellers Motivational Model - IS Theory," theorizeit.org, 2012,

https://is.theorizeit.org/wiki/Kellers_Motivational_Model, (accessed 11 September 2020).

[15] Iversen G.R., Norpoth H., "Analysis of variance", Series: Quantitative Applications in the Social Sciences, 2nd ed., Sage Publications, Newbury Park, CA, 1987.

[16] Keller, J.M. "Motivation and instructional design: A theoretical perspective," Journal of Instructional Development, vol 2, no. 24, 1979, pp. 26-34.

[17] Keller J.M., Kopp T.W., "An application of the ARCS model of motivational design. In C.M. Reigeluth (ed.), Instructional theories in action: Lessons illustrating selected theories and models, Hillsdale NJ: Lawrence Erlbraum Associates, 1987, pp. 289-320.

[18] Keller John M., "Motivation, Learning and Technology: Applying the ARCS-V Motivation Model," Participatory Educational Research, vol. 3, no. 2, 2016, pp. 1-13.

[19] Keller John M., Motivational Design for Learning and Performance: The ARCS Model Approach. New York: Springer, 2010.
[20] Kumar A., "Blended Learning in Higher Education: A Comprehensive Study," Proceedings of International Conference on Business, 2012 , http://ojs.ijacp.org/index.php/ICBMIS/article/view/82.

[21] Lütge, Christiane et al. "Crossovers: Digitalization and Literature in Foreign Language Education," Studies in Second Language Learning and Teaching, vol. 9, no. 3, 2019, pp. 519-540.

[22] Malhotra, N., Dash, S., "Marketing Research - An Applied Orientation," 6th ed., Dorling Kindersley, New Delhi: Licensees of Pearson Education in South Asia, 2011.

[23] "The Annual Statistical Report on Higher Education In Jordan For The Year 2015-2016," Ministry of Higher Education \& Scientific Research. 2016, http://www.mohe.gov.jo/en/pages/Statistics.aspx, (accessed 11 September 2020).

[24] Nilsson Maria, "Beliefs and experiences in the English classroom: Perspectives of Swedish primary school learners," Studies in Second Language Learning and Teaching. vol. 10, no. 2, 2020, pp. 257-281.

[25] Nunnally J.C., Psychometric Theory, McGraw-Hill, New York, NY, 1978.

[26] "Online College Students by The Numbers," Onlinecolleges. Net. 2020,https://www.onlinecolleges.net/for-students/onli ne-college-students-by-the-numbers/ (accessed 9 September 2020).

[27] "The History Of Online Schooling," Online schools, 2020, https://www.onlineschools.org/visual-academy/the-history -of-online-schooling/ (accessed 9 September 2020).

[28] Pappas C., Instructional Design Models and Theories. Keller'S ARCS Model Of Motivation - Elearning Industry, E-learning Industry, 2015, https://elearningindustry.com/ar cs-model-of-motivation (accessed 11 September 2020).

[29] Pintrich Paul R., "A Motivational Science Perspective on the Role of Student Motivation in Learning and Teaching Contexts," Journal of Educational Psychology. vol. 95, no. 4, 2003, pp. 667-686.

[30] Parsad B., Lewis L. "Distance Education at Degree-Granting Postsecondary Institutions: 2006-07," Washington DC: National Center for Education Statistics, Institute of Education Sciences, US Department of Education, 2008, https://nces.ed.gov/pubs2009/2009044.pdf.

[31] Ross B., K. Gage, "Global perspectives on blended learning: Insight from WebCT and our customers in higher education," in C. J. Bonk, C. R. Graham (eds.) Handbook of Blended Learning: Global Perspectives, Local Designs. San Francisco, CA: Pfeiffer, 2006, pp.155-168.

[32] 'Education Strategic Plan 2018-2022," UNESCO, 2018, http://www.unesco.org/new/fileadmin/MULTIMEDIA/FIE LD/Amman/pdf/ESP_English.pdf, (accessed 10 September 2020). 